\title{
Seasonal breeding in birds and its implications for the conservation of biodiversity in the Oku region, Cameroon
}

\author{
ROGER C. FOTSO
}

\section{Summary}

The breeding activity of birds in the Oku region of Cameroon appears to be highly seasonal, with the majority of species breeding exclusively during the months of the dry season, November to April. Forest fires, which in the dry season often destroy large areas of suitable habitat, are likely to strongly influence nest failures in many species, including some endemic and endangered ones.

\section{Introduction}

Moist mountain forest in western Cameroon covers an area of approximately $4500 \mathrm{~km}^{2}$ (Gartlan 1989). This fragile ecosystem of high endemicity, with many species at risk of extinction (Collar and Stuart 1985), is under severe pressure from agriculture, as the fertile volcanic soil of the area has attracted a large human population.

In contrast to the adjacent areas of lowland rainforest, which show very little change. in climatic conditions between dry and wet seasons, except for the volume of rainfall, the climate in the mountain region of western Cameroon is highly seasonal with a clear-cut dry season from November to April and a wet season from May to October. In the Oku region, extensive forest fires, many started accidentally by farmers who commonly use fire to clear old plantations, occur at the peak of the dry season in January and February. The wet season is characterized by prolonged rain and thick mist which envelops the forest from July to September.

Bird assemblages are known to be very sensitive to environmental changes. My aim was to demonstrate the influence of seasonal changes in climate on the biological rhythm of species and the implications of seasonality in birds for the conservation of biological diversity in the region.

\section{Study area and methods}

The Oku region $\left(6^{\circ} 12^{\prime} \mathrm{N} 10^{\circ} 31^{\prime} \mathrm{E}\right)$ is situated in the northern section of the Bamenda Highlands (Figure 1), close to the contact zone between the mountain forest and the savanna in the north. The study site was located on the northern slope of the Oku Mountain and is one of the best preserved fragments of mountain forest in the region (Figure 1). 


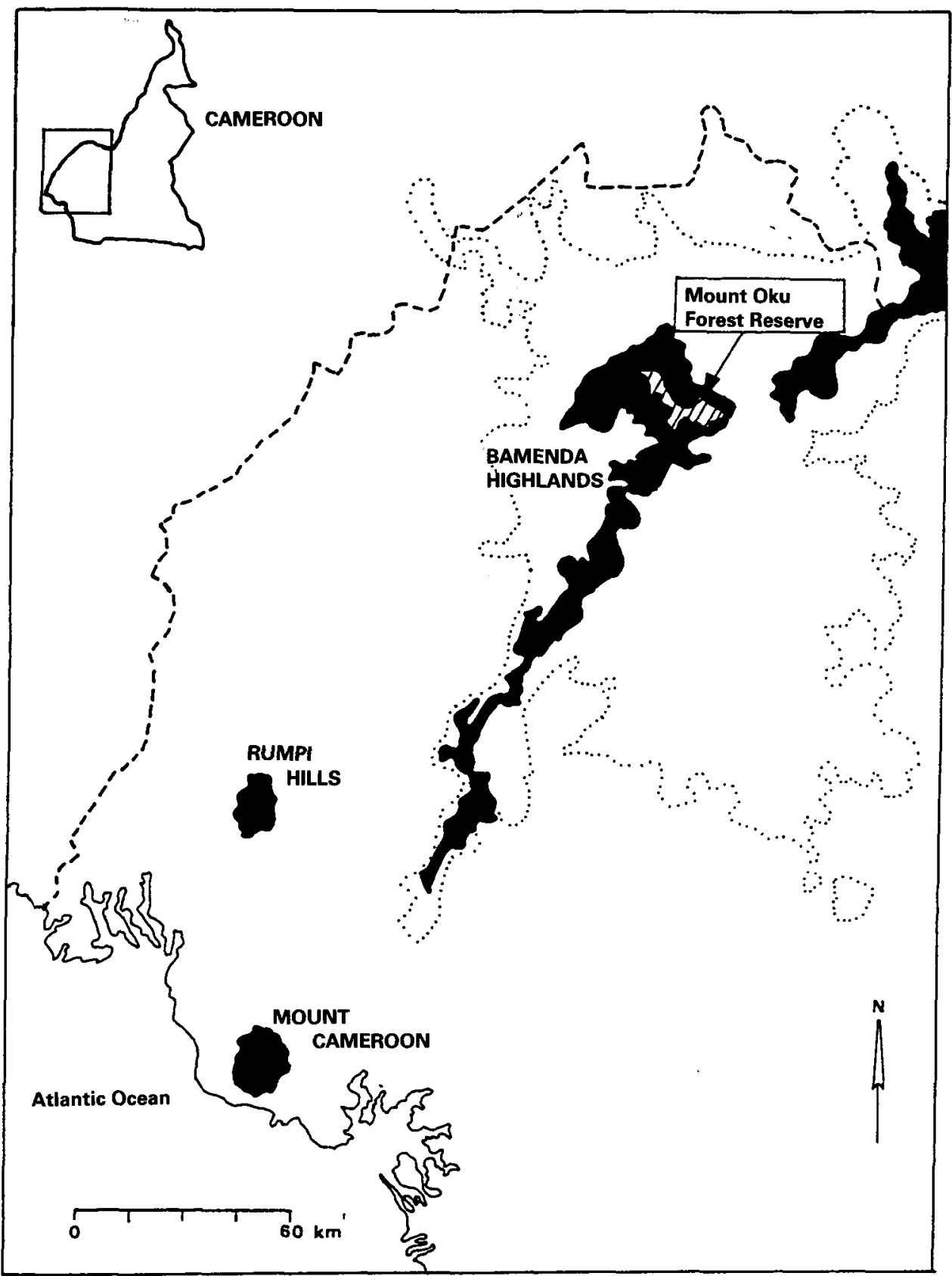

Figure 1. Cameroon mountain ridge and the range of Afromontane vegetation (black). The dotted line indicates the contour line at $900 \mathrm{~m}$. 
The vegetation structure in the area includes moist mountain forest, degraded forest and bamboo Arundinaria alpina forest. The forest shows structural and floristic changes related to altitude; at lower altitudes the forest is dominated by Schefflera abyssinica and Carapa grandiflora, while at higher altitudes it is dominated by Syzygium staudtii, Rapanea neuroflora and Podocarpus milajianus (Thomas 1987). The forest understorey is characterized by Ardisia cymosa, Psychotria peduncularis and Brillantaisia sp.

Between $2400 \mathrm{~m}$ and $2700 \mathrm{~m}$ bamboo becomes increasingly common and forms species-poor stands, especially on steep slopes. Above $2600 \mathrm{~m}$ the forest changes in character to become much more open and dominated by Podocarpus millanjianu and stands of bamboo. This is the most western and the only location in West Africa where this botanical formation occurs, although it is well developed in eastern Africa (Letouzey 1968).

Very few trees, the majority of which are exotic (mainly Eucalyptus), grow in the cultivated lands. There is no transition zone between forest and cultivation, nor between forest and savanna at the summit plateau.

Birds were recorded along pre-established transects in the forest, running from the farm border at around $2100 \mathrm{~m}$ up to the summit plateau at $2900 \mathrm{~m}$. Some areas of mixed farm and grassland around the villages at about $1800 \mathrm{~m}$ were also searched. A concerted effort was made to locate as many nests as possible, with the aim of identifying the length of the breeding season of species present in the area. Most searching activity was concentrated within an area of about 200 ha along the transects.

\section{Results and discussion}

Intensive searches for nests within an area of about 200 ha in 1990 and 1991 showed that at least $4 \pi$ species breed in the area (Table 1 ). This includes some 27 species for which the nest itself, containing eggs or young, was found. Other species were seen with newly fledged young and their laying date estimated according to the approximate age of juveniles. For some species, e.g. Cameroon Mountain Greenbul Andropadus montanus, this is the first record of their nest.

The majority of nests were reported during the dry season (Table 1) but some species seem to breed only after the rains have started (Mountain Robin Cossypha isabellae, West Africa Thrush Turdus pelios, Bannerman's Turaco Tauraco bannermani). About $65 \%$ of the nests of forest dependent species were located between $2200 \mathrm{~m}$ and $2500 \mathrm{~m}$. No nests were found in the area after June. The breeding season for the bird assemblage in the region therefore extends from October to June (Figure 2), with a peak during the dry season (February and March), as also suggested by Eisenthraut (1963) and Serle (1981).

Breeding was not concentrated in the first two months of the dry season (November and December) as suggested by Tye (1992) but rather it extended over several months. The nests of some species, e.g. Western Mountain Greenbul Andropadus tephrolaemus, African Hill Babbler Alcippe abyssinica and Banded Wattle-eye Platysteira laticincta were reported throughout the breeding period for the region. 
Table 1. Laying dates for birds in the Oku region of Cameroon, 1990 and 1991

\begin{tabular}{|c|c|c|c|c|c|c|c|c|c|c|c|c|}
\hline & $\mathrm{S}$ & $\mathrm{O}$ & $\mathrm{N}$ & D & $\mathrm{J}$ & $\mathbf{F}$ & $\mathbf{M}$ & A & $\mathbf{M}$ & $\mathrm{J}$ & $\mathrm{J}$ & A \\
\hline Black Kite Milvus migrans & & & & & & 3 & & $\mathbf{1}$ & & & & \\
\hline African Goshawk Accipiter tachiro & & & & & & & $\mathbf{1}$ & & & & & \\
\hline Red-necked Buzzard Buteo auguralis & & & & & & 1 & $\mathbf{1}$ & & & & & \\
\hline $\begin{array}{l}\text { Crowned Hawk-eagle Stephanoaetus } \\
\text { coronatus }\end{array}$ & & $\underline{\mathbf{1}}$ & & $\underline{1}$ & & & & & & & & \\
\hline Scaly Francolin Francolinus squamatus & & & & & & $\underline{I}$ & & & & & & \\
\hline Olive Pigeon Columba arquatrix & & & & & & 1 & 6 & 4 & 5 & & & \\
\hline Bannerman's Turaco Tauraco bannermani & & & & & & & 7 & 33 & 23 & 3 & & \\
\hline Speckled Mousebird Colius striatus & & & & & & 3 & 2 & & & & & \\
\hline Bar-tailed Trogon Apaloderma vitatum & & & & & & $\underline{1}$ & & & & & & \\
\hline $\begin{array}{l}\text { White-headed Wood Hoope Phoeniculus } \\
\text { bolei }\end{array}$ & & & & & 3 & & & & & & & \\
\hline Grey Cuckoo-shrike Coracina caesia & & & & & & $\underline{2}$ & $\mathbf{1}$ & 2 & & & & \\
\hline $\begin{array}{l}\text { Cameroon Mountain Greenbul } \\
\text { Andropadus montanus }\end{array}$ & & & & & & & 3 & & 1 & & & \\
\hline $\begin{array}{l}\text { Western Mountain Greenbul Andropadus } \\
\text { tephrolaemus }\end{array}$ & & & & & $\mathbf{1}$ & 4 & 5 & 3 & 9 & & & \\
\hline $\begin{array}{l}\text { Cameroon Olive Greenbul Phyllastrephus } \\
\text { poensis }\end{array}$ & & & & & & & $\mathbf{1}$ & & & & & \\
\hline West African Thrush Turdus pelios & & & & & & & $\underline{\mathbf{1}}$ & 1 & 1 & & & \\
\hline Mountain Robin Cossypha isabellae & & & & & & & $\overline{1}$ & 3 & 4 & & & \\
\hline Stonechat Saxicola torquata & & & 1 & & & & 1 & & & & & \\
\hline Chubb's Cisticola Cisticola chubbi & & $\underline{1}$ & $\underline{\mathbf{1}}$ & 1 & 2 & $\underline{1}$ & $\mathbf{I}$ & & & & & \\
\hline Green Longtail Urolais epichlora & & & & & $\underline{1}$ & $\underline{\mathbf{1}}$ & $\underline{1}$ & & & & & \\
\hline Black-collared Apalis Apalis pulchra & & & & 3 & $\overline{1}$ & $\overline{3}$ & $\overline{1}$ & & 1 & $\mathbf{1}$ & & \\
\hline Black-throated Apalis Apalis jacksoni & & $\underline{2}$ & & & & & & & & & & \\
\hline Grey Apalis Apalis cinerea & & & $\underline{1}$ & $\underline{2}$ & $\underline{2}$ & $\underline{2}$ & & & & & & \\
\hline Dusky Flycatcher Muscicapa adusta & & $\underline{2}$ & 3 & $\underline{2}$ & 3 & 3 & $\mathbf{I}$ & 2 & & & & \\
\hline Banded Wattle-eye Platysteira laticincta & & $\overline{2}$ & 5 & $\overline{8}$ & 4 & 6 & 2 & $\mathbf{1}$ & & & & \\
\hline $\begin{array}{l}\text { White-billed Crested Flycatcher Elminia } \\
\text { albiventris }\end{array}$ & & & & & & 2 & 2 & & & & & \\
\hline African Hill Babbler Alcippe abyssinica & & & & & 3 & 4 & 3 & 9 & 14 & 2 & & \\
\hline White-billed Tit Parvus albiventris & & & & & & 1 & & & 1 & & & \\
\hline $\begin{array}{l}\text { Cameroon Blue-headed Sunbird } \\
\text { Nectarinia oritis }\end{array}$ & & & & & & & & 1 & & $\mathbf{1}$ & & \\
\hline $\begin{array}{l}\text { Northern Double-collared Sunbird } \\
\text { Nectarinia preussi }\end{array}$ & & & & & & & $\mathbf{1}$ & 1 & & & & \\
\hline Bannerman's Weaver Ploceus bannermani & & & & & & & $\mathbf{1}$ & $\mathbf{1}$ & 1 & & & \\
\hline Black-billed Weaver Ploceus melanogaster & & & & & & $\underline{1}$ & ' & & & & & \\
\hline Brown-capped Weaver Ploceus insigni & & & & & & & 1 & & & & & \\
\hline Yellow White-eye Zosterops senegalensis & & & $\mathbf{1}$ & & & & & 1 & & 1 & & \\
\hline Black-winged Oriole Oriolus nigripenis & & & & & & $\underline{1}$ & & & & & & \\
\hline Mackinnon's Shrike Lanius mackinnoni & & & & 1 & & & & & & & & \\
\hline $\begin{array}{l}\text { Yellow-breasted Boubou Lanius } \\
\text { atroflavus }\end{array}$ & & & & & 1 & & $\underline{1}$ & 1 & 1 & & & \\
\hline Red-winged Starling Onychognatus morio & & & & & & $\mathbf{I}$ & 1 & & & & & \\
\hline $\begin{array}{l}\text { Red-faced Crimson-wing Crytospiza } \\
\quad \text { reichenowii }\end{array}$ & & & & $\underline{\mathbf{1}}$ & $\underline{2}$ & $\mathbf{I}$ & & 1 & & & & \\
\hline Thick-billed Seed-eater Serinus burtoni & & & & $\underline{1}$ & & & & & & & & \\
\hline Oriole-Finch Linurgus olivaceus & & & & & 1 & & & & & & & \\
\hline Cabanis's Bunting Emberiza cabanisi & & & & & & & $\underline{2}$ & & & & & \\
\hline
\end{tabular}

Cabanis's Bunting Emberiza cabanisi

Underlined values are estimated laying dates. Dates for Bannerman's Turaco were collected over four years. 

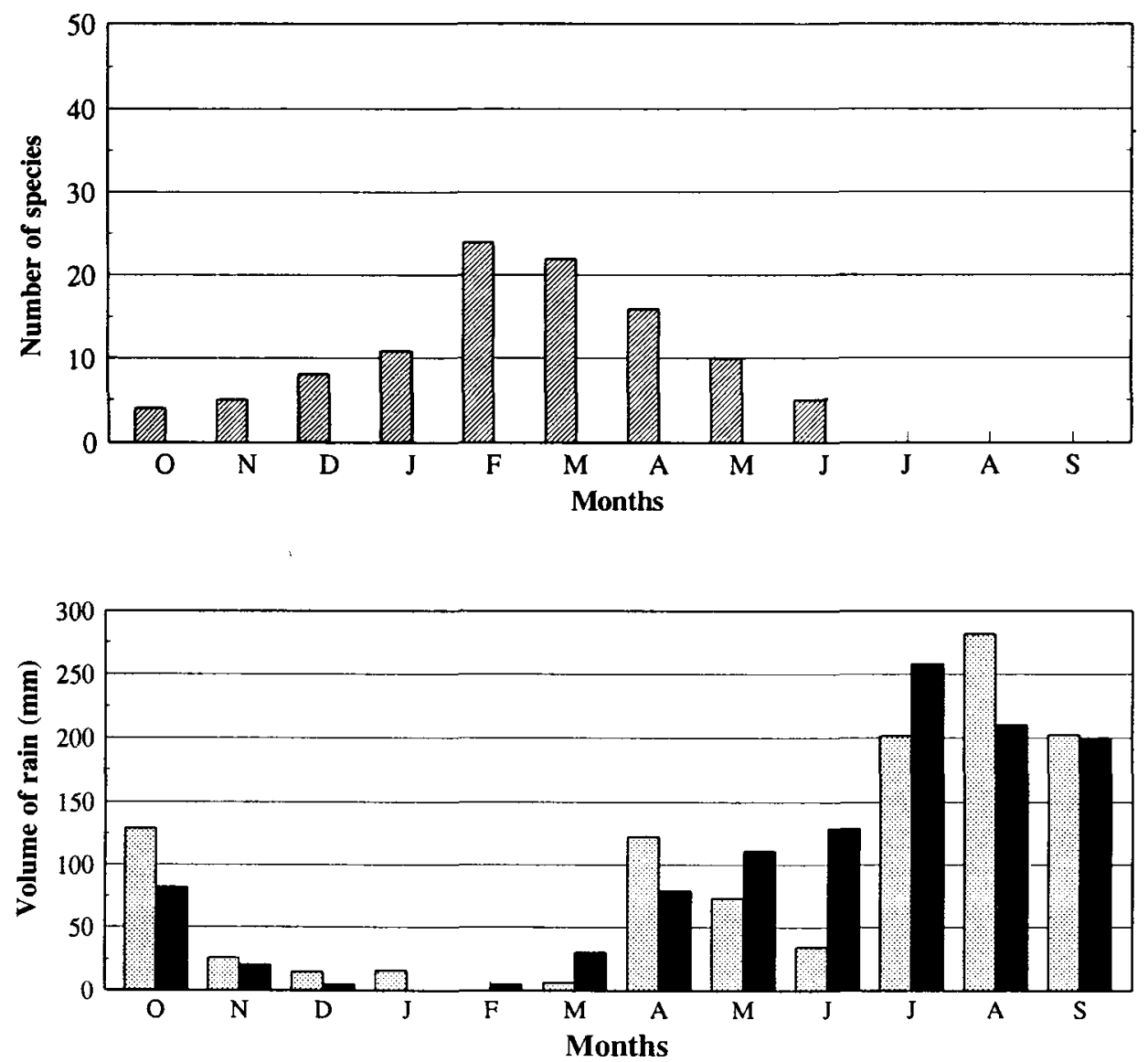

First half in the month

Second half in the month

Figure 2. Correspondence between the breeding period and the volume of rainfall in the Oku region. The number of breeding pairs of Bannerman's Turaco Tauraco bannermani and Black-throated Wattle-eye Platysteira laticincta are not included since they are discussed elsewhere.

In contrast to tropical lowland rainforest, where the start of the rainy season seems to be the proximate factor initiating the annual reproduction of forest birds (Brosset 1990), nesting activities commence in the mountain forest with the onset of the dry season (Figure 2). However, the ultimate factor is likely to be the same as for lowland forest birds, increasing primary and secondary production (Brosset and Erard 1986). In fact, the majority of species breeding at the height of the dry season are insectivores (warblers, flycatchers), which can hunt for insects in the dry vegetation. Omnivores (thrushes) and frugivores (turacos) breed during the early months of the rainy season when many trees bear fruit. As suggested by Serle (1981), the absence of breeding in the area from July to October may be a consequence of prolonged rain and thick mist 
causing a shortage of food due to its inhibitory effect on production of both plants and animals.

\section{Threats to bird assemblages}

The weather in the region is too cool for the majority of snakes which prey on bird nests in the lowland rainforest. Predators of bird nests in the area are monkeys and squirrels, although the Yellow-breasted Shrike Laniarius atroflavus may destroy a number of nests of small birds. However, the major threat to the bird assemblage is agricultural encroachment, with more and more forest cleared for farms, and above all fires which, in January and February, often destroy extensive areas of forest.

The pressure on the forest for more agricultural land has been reduced considerably since the start of mountain forest conservation projects in the region by BirdLife International in 1988 and 1992. Nevertheless, forest fires, started accidentally by farmers and beekeepers, continue to cause serious damage to the forest and bird assemblages as they coincide with the peak of the breeding season for many bird species, including endemics (Black-collared Apalis Apalis pulchra and Western Mountain Greenbul) and others at risk of extinction (Banded Wattle-eye). It will, therefore, be very difficult to preserve the biological diversity of the region unless the use of fire is banned, or very carefully monitored when unavoidable. The use of fire may be controlled if a buffer zone is maintained between the forest and farms, and farmers are encouraged to protect their farms with a system of fire breaks. Beekeepers must be instructed to ensure that they put out fires used to drive bees away from hives.

\section{Acknowledgements}

This work was part of a study sponsored by the Fauna and Flora Preservation Society through the BirdLife International project for the conservation of the Kilum Mountain Forest. I am grateful to all those who helped me. Special thanks are extended to J. and $\mathrm{H}$. Parrott who advised and encouraged me, to Dr. M. Louette for helpful comments on the manuscript and to Ernest Kening, the local field assistant who contributed so much information. G. Bockett and S. Menzepo also provided information.

\section{References}

Brosset, A. (1990) A long-term study of the rain forest birds in M'passa (Gabon). Pp. 259274 in A. Keast, ed. Biogeography and ecology of forest bird communities. London: Academic Press.

Brosset, A. and Erard, C. (1986) Les oiseaux des régions forestières du nord-est du Gabon, I. Paris: Société Nationale de Protection de la Nature.

Collar, N. J. and Stuart, S. N. (1985) Threatened birds of Africa and related islands: the ICBP/ IUCN red data book. Cambridge, U.K.: International Council for Bird Preservation and International Union for Conservation of Nature and Natural Resources.

Eisentraut, M. (1963) Die Wirbeltiere des Kamerungebirges. Hamburg: P. Parey. 
Gartlan, S. (1989) La conservation des ecosystémes forestiers du Cameroun. IUCN Programme for Tropical Forests. Gland, Switzerland: International Union for Conservation of Nature and Natural Resources.

Letouzey, R. (1968) Etude phytogéographique du Cameroun. Paris: Lechevalier Encyclopedie Biologique 69.

Serle, $W$. (1981) The breeding season of birds in lowland rainforest and in the montane forest of west Cameroon. Ibis 123: 62-74.

Thomas, D. W. (1987) Vegetation of Mount Oku. In H. M. Macleod, ed., The conservation of Oku Mountain forest, Cameroon. Cambridge, UK.: International Council for Bird Preservation.

Tye, H. (1992) Reversal of breeding season by lowland birds at higher altitudes in western Cameroon. Ibis 134: 154-163.

ROGER C. FOTSO,

Zoological Institute K.U. Leuven, Naamsestraat 59 B30oo Leuven, Belgium.

Present address: clo ECOFAC/CAMEROUN, B.P. 13844, Yaounde, Cameroon. 